\title{
Cellular and nuclear morphology....and calcium signaling: revealing the interplay between structure and function
}

\author{
Markus Breit ${ }^{1 *}$, Peter Bengtson², Anna Hagenston², Hilmar Bading ${ }^{2}$, Gillian Queisser $^{1}$ \\ From Twenty First Annual Computational Neuroscience Meeting: CNS*2012 \\ Decatur, GA, USA. 21-26 July 2012
}

Calcium plays a pivotal role in relaying electrical signals of the cell to subcellular compartments, such as the nucleus. Since this one ion type is used by the cell for many processes a neuron needs to establish finely tuned calcium pathways in order to be able to differentiate multiple tasks, [1-3].

While it is known that neurons can actively change their shape upon neuronal activity, [4-7], we here present novel findings of activity-regulated nuclear morphology, $[8,9]$. With the help of an experimental and computational modeling approach, we show that hippocampal neurons can change the previously spherical shape of their nuclei to complex and infolded morphologies. This morphology regulation is demonstrated to be regulated by NMDA-receptor gated calcium, while synaptic and extra-synaptic NMDA-receptors elicit opposing effects on nuclear morphology, [8].

The structural alterations of the cell nucleus have significant effects on nuclear calcium dynamics. Compartmentalization of the nucleus, due to membrane infoldings, changes calcium frequencies, amplitudes and spatial distributions, $[8,10]$. Since these parameters have been shown to control downstream events towards gene transcription, $[11,12]$, the results elucidate the cellular control of nuclear function with the help of morphology modulation. With respect to processes downstream of calcium, we show that histone $\mathrm{H} 3$ phosphorylation is closely linked to nuclear morphology. Investigating the nuclear morphologies of hippocampal neurons, two major classes were identified $[9,10]$. One class contains non-infolded nuclei that have the function of calcium signal integrators, while the other

'Goethe Center for Scientific Computing, Computational Neuroscience Group, University of Frankfurt, Frankfurt am Main, 60325, Germany Full list of author information is available at the end of the article class contains highly infolded nuclei, which function as frequency detectors of nuclear calcium, [10].

Extending this interdisciplinary approach of investigating structure/function relationships in neurons, the effects of cellular morphology - as well as the morphology of the endoplasmic reticulum and other organelles - on neuronal calcium signals is currently being investigated. This endeavor makes use of highly detailed, three-dimensional models of neuronal calcium dynamics, including the three-dimensional morphology of the cell and its organelles.

\section{Author details}

${ }^{1}$ Goethe Center for Scientific Computing, Computational Neuroscience Group, University of Frankfurt, Frankfurt am Main, 60325, Germany. 2Department of Neurobiology, Interdisciplinary Center for Neuroscience, University of Heidelberg, Heidelberg, 68120, Germany.

\section{Published: 16 July 2012}

\section{References}

1. Milner $B$, Squire LR, Kandel ER: Cognitive neuroscience and the study of memory. Neuron 1998, 20:445- 468.

2. Bading $\mathrm{H}$ : Transcription-dependent neuronal plasticity: the nuclear calcium hypothesis. Eur J Biochem 2000, 267:5280-5283.

3. West AE, Griffith EC, Greenberg ME: Regulation of transcription factors by neuronal activity. Nat Rev Neurosci 2002, 3:921-931.

4. Muller D, Nikonenko I, Jourdain P, Alberi S: LTP, memory and structural plasticity. Curr Mol Med 2002, 2:605- 611.

5. Van Aelst L, Cline HT: Rho GTPases and activity-dependent dendrite development. Curr Opin Neurobiol 2004, 14:297-304.

6. Hayashi Y, Majewska AK: Dendritic spine geometry: functional implication and regulation. Neuron 2005, 46:529-532

7. Tada T, Sheng M: Molecular mechanisms of dendritic spine morphogenesis. Curr Opin Neurobiol 2006, 16:95-101.

8. Wittmann M, Queisser G, Eder A, Wiegert JS, Bengtson CP, Hellwig A, Wittum G, Bading H: Synaptic activity induces dramatic changes in the geometry of the cell nucleus: interplay between nuclear structure, histone $\mathrm{H} 3$ phosphorylation and nuclear calcium signaling. J Neurosci 2009, 29:14687-700. 
9. Queisser G, Wittmann M, Bading H, Wittum G: Filtering, reconstruction and measurement of the geometry of nuclei from hippocampal neurons based on confocal microscopy data. J Biomed Opt 2008, 13:14009.

10. Queisser $\mathrm{G}$, Wiegert $\mathrm{S}$, Bading $\mathrm{H}$ : Structural dynamics of the cell nucleus: Basis for morphology modulation of nuclear calcium signaling and gene transcription. Nucleus 2011, 2(2):98-104.

11. De Koninck P, Schulman H: Sensitivity of CaM kinase II to the frequency of Ca2+ oscillations. Science 1998, 279:227-230.

12. Dolmetsch RE, Lewis RS, Goodnow CC, Healy Jl: Differential activation of transcription factors induced by $\mathrm{Ca} 2+$ response amplitude and duration. Nature 1997, 386:855- 858.

doi:10.1186/1471-2202-13-S1-P65

Cite this article as: Breit et al: Cellular and nuclear morphology.... and

calcium signaling: revealing the interplay between structure and function. BMC Neuroscience 2012 13(Suppl 1):P65.

\section{Submit your next manuscript to BioMed Central} and take full advantage of:

- Convenient online submission

- Thorough peer review

- No space constraints or color figure charges

- Immediate publication on acceptance

- Inclusion in PubMed, CAS, Scopus and Google Scholar

- Research which is freely available for redistribution

Submit your manuscript at www.biomedcentral.com/submit
C Biomed Central 